\title{
Experimental and density functional theory studies of some novel piperidine-containing acetylene glycols
}

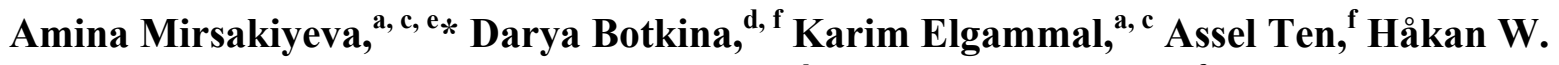
Hugosson, ${ }^{a}$ Anna Delin, ${ }^{a, b, c}$ and Valentina $Y u^{e, f}$

${ }^{a}$ Department of Materials and Nano Physics, School of Information and Communication Technology, KTH Royal Institute of Technology, Electrum 229, SE-16440 Kista, Sweden

${ }^{b}$ Department of Physics and Astronomy, Materials Theory Division, Uppsala University, Box 516 , SE-75120 Uppsala, Sweden

${ }^{c}$ Swedish e-Science Research Center (SeRC), KTH Royal Institute of Technology, SE-10044 Stockholm, Sweden

${ }^{d}$ Department of Production Engineering, School of Industrial Engineering and Management, KTH Royal Institute of Technology, Brinellvägen 68, 10044 Stockholm, Sweden

${ }^{e}$ Kazakh-British Technical University, Department of Chemical Engineering, Tole bi 59, 050000 Almaty, Kazakhstan

${ }^{f}$ Institute of Chemical Sciences, Walikhanov str. 106, 050010, Almaty city, Kazakhstan E-mail: aminami@kth.se

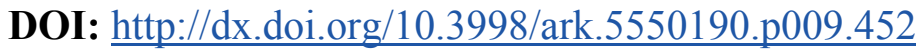

\begin{abstract}
Synthesis routes of novel piperidine-containing acetylenes are presented. The new molecules are expected to exhibit plant growth stimulation properties. In particular, the yield in a situation of drought is expected to increase. Our synthesis makes use of the Favorskii reaction between cyclohexanone/piperidone and triple-bond containing alcohols. The structures of the obtained molecules were determined using nuclear magnetic resonance (NMR). The electronic structure and geometries of the molecules were studied theoretically using first-principles calculations based on density functional theory. The calculated geometries agree very well with the experimentally determined ones, and also allow us to determine bond lengths, angles and charge distributions inside the molecules.
\end{abstract}

Keywords: Piperidine, acetylene glycols, CPMD, MD, density functional theory, plant growth stimulation

\section{Introduction}

Piperidine-containing compounds have shown great promise as plant growth stimulators ${ }^{1-5}$ (Figure $1)$. 

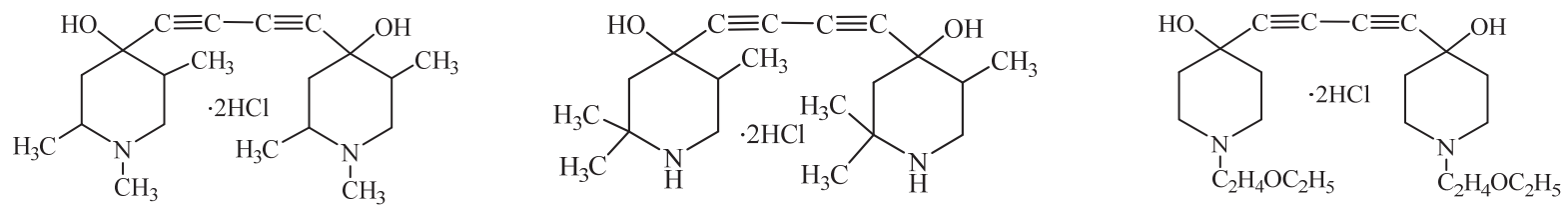

Figure 1. Piperidine-containing diacetylene glycols.

Nowadays in the world one out of eight people does not get enough food. ${ }^{6}$ It brings the problem of hunger and malnutrition to the first position as a challenge to human health - greater than AIDS, malaria, and tuberculosis combined. ${ }^{7-10}$ A prospective solution to the hunger problem may be offered through compounds that have the ability to increase crop yield, for example, by making crops more drought resistant. It is well known that the use of piperidine-containing diacetylene glycols may increase the growth of plants multifold. ${ }^{1-5}$ In addition, plants which were processed by piperidine-containing diacetylene glycols prove to be more resistant to drought, temperature changes and diseases. ${ }^{1-5}$ Treatment by piperidine-containing diacetylene glycols can rapidly increase the annual harvest, especially in hot and arid regions. The synthesis of piperidinecontaining acetylene glycols is however relatively complicated. It includes ethynylation of piperidone-4 in liquid ammonia or diethyl ether in the presence of solid potassium hydroxide. After extraction the purified acetylenic glycols dimerize and form diacetylene glycol. Dimerization of acetylenic glycols is provided by oxidation in the presence of cuprous (I) chloride $\left(\mathrm{Cu}_{2} \mathrm{Cl}_{2}\right)$ and pyridine. $^{1,2,5}$

In the present work a new type of compounds with potentially similar positive effects on crop yield and drought resistance was synthesized and studied both experimentally and theoretically. Piperidine-based acetylene glycols were synthesized under the Favorskii reaction. ${ }^{11}$ The Favorskii reaction is used for piperidine acetylene glycols synthesis and can be defined as the nucleophilic attack of an alkynyl anion on a carbonyl group of ketone. ${ }^{12}$ For the syntheses two alcohols with triple bond were chosen: propargyl alcohol (Figure 2a) and 3-butyn-1-ol (Figure 2b).

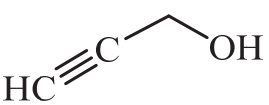

$\mathrm{a}$

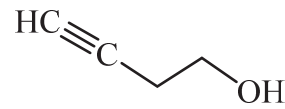

b

Figure 2. (a) Propargyl alcohol (3); (b) 3-butyn-1-ol (4).

Both alcohols have low crystallization temperature $\left(-48{ }^{\circ} \mathrm{C}\right.$ for propargyl alcohol and $-64{ }^{\circ} \mathrm{C}$ for 3-butyn-1-ol) which lets the reaction take place under $0-4{ }^{\circ} \mathrm{C}$. During this study the propargyl (3) and 3-butyn-1-ol (4) alcohols were used in combination with 1-(2-etoxyethyl)piperidine-4-on (1) and cyclohexanone (2) as model structure to create 1-(2-ethoxyethyl)-4-(3-hydroxypropynyl1)piperidine-4-ol (7), 1-(2-ethoxyethyl)-4-(4-hydroxybutynyl-1)piperidine-4-ol (8), 1-(3hydroxypropynyl-1)cyclohexanol (5) and 1-(4-hydroxybutynyl-1)cyclohexanol (6). However, the yields were low in the reactions under the standard conditions, whereas the duration of synthesis 
was long. That could be caused by the effect of the solvent, the reactivity of the raw materials with each other, or the instability of molecules and intermolecular interaction. In order to elucidate the origin of the latter possibility, we perform theoretical studies of the molecules under realistic conditions, assuming ambient temperature. The quantum mechanical (QM) simulations allow us to determine the detailed structure of the novel molecules (including the bond lengths, the angles and the electronic structure). Furthermore, such simulations allow us to determine whether the molecules are stable or not. This is important since if they were unstable that would be the explanation for the low production rate. In addition, using our theoretical analysis we are able to suggest possible chemical reactions to be studied further experimentally.

Numerous theoretical electronic structure studies using density functional theory (DFT) ${ }^{13}$ and Hartree-Fock (HF) method investigating the structure and reactivity of acetylene and piperidine/cyclohexane ring containing compounds have been presented earlier. ${ }^{14-20}$ Common to all these studies is that the triple bond has been found to have high reactivity. Also there is strong interest in studying the chemical reactivity of these novel materials being used as catalysts. ${ }^{14,15} \mathrm{~A}$ number of works investigate the chemical reaction mechanisms. ${ }^{16,17}$ DFT calculations of piperidine compounds have also been performed to determine the heat of formation. ${ }^{18}$ An earlier investigation has convincingly demonstrated the high accuracy and agreement between DFT methods and experimental results for 4-methylpiperidine. ${ }^{19}$ This gives confidence that these methods are suitable for further studies of this group of compounds. For 4-piperidone the ground state (HOMO) and first excited state (LUMO) were found, and the structure was determined both with theoretical (HF and DFT) and empirical (IR) methods. ${ }^{20}$ However, we have found no previous theoretical research for molecules containing both piperidine/cyclohexane rings and triple bonds. In the theoretical part of this research, DFT calculations of piperidine-containing acetylene glycols were performed. New molecules were built and first optimized using the AVOGADRO software. ${ }^{21}$ Applying CarParrinello Molecular Dynamics ${ }^{22}$ allowed determining the ground-state structure of these novel compounds. The charge density difference was also studied via the Quantum Espresso code ${ }^{23}$ and visualized through XCrysDen. ${ }^{24}$

\section{Method of theoretical calculations}

The structures of the piperidine-containing acetylene glycols were built using the AVOGADRO software. QM calculations based on DFT were performed using the Car-Parrinello Molecular Dynamics package (CPMD). An orthorhombic simulation box with a size of $(\boldsymbol{a}+8)^{3} \AA$, where $\boldsymbol{a}$ is a length of the organic molecules (varying between 20-30 $\AA$ ), was used. The pseudo-potentials were of the soft norm-conserving Troullier-Martins type, with a cut-off of $90 \mathrm{Ry}$. We used the exchangecorrelation functional BLYP. ${ }^{25,}{ }^{26}$ The initial quenching was combined with annealing down to $\mathrm{E}_{\mathrm{kin}}=0 \mathrm{eV}$ for $0.483 \mathrm{ps}$. In this context quenching refers to the converging the wavefunctions at the beginning of a run, and annealing refers to scaling of the ionic velocities towards zero. This equilibration procedure was followed by 4 ps of temperature controlled molecular dynamics calculations (velocity scaling $300 \mathrm{~K}$ with $\Delta \mathrm{T}=+/-20 \mathrm{~K}$ ). After that the calculations were followed by around 6 ps of molecular dynamics simulations at $300 \mathrm{~K}$ using a Nosé-Hoover thermostat, ${ }^{27}$ during which we collected statistics for our analysis. In order to determine the average structure and 
charge distribution, we extracted bond lengths and angles in every simulation step of the calculations under the Nosé-Hoover thermostat. The CPMD code uses a R-ESP method to calculate the point charges from the electrostatic potential restricted to charges from the Hirshfeld method. ${ }^{28,}$

${ }^{29}$ For charge distribution studies an additional 4.8 ps of Nosé-Hoover calculation were performed while constantly collecting charges every $10^{\text {th }}$ steps $(0.00483 \mathrm{ps})$.

Finally, charge density difference (CDD) plots were generated via ground state DFT calculations using the Quantum Espresso simulation package with a setup similar to the CPMD simulations. The CDD is calculated by subtracting the charge density of the free atoms from the molecule charge density.

\section{Results and Analysis of Theoretical Calculations}

Below, we present our results on bond lengths and bond angles, point charge distributions, CDD, and frontier orbitals.

\section{Structure (bond lengths and angles)}

The average bond lengths for the studied molecules were determined. We here choose to concentrate our analysis on the acetylene bonds since for our purposes this is the most chemically relevant part of the electronic structure. In Table 1 we show our data for the triple bond of the substitute radical and ethers bonds. From this table, we can see that $\mathrm{a}_{2}$ is significantly shorter than $\mathrm{a}_{1}$ and $\mathrm{a}_{3}$ (1.2 $\AA$ compared to 1.4-1.5 $\AA$ ), which strongly suggests that the $\mathrm{a}_{2}$ bond is a triple bond. This is an excellent agreement with the NMR results (see Experimental section).

Table 1. Bond lengths (in $\AA$ ) from calculations using Nosé-Hoover thermostat. Standard deviations are given within parentheses

\begin{tabular}{cccccc}
\hline & $\mathrm{a}_{1}\left(\mathrm{C}_{\text {ring- }}-\mathrm{C}\right)$ & $\mathrm{a}_{2}\left(\mathrm{C}_{\text {triple-C}}-\mathrm{a}\right.$ & $\mathrm{a}_{3}(\mathrm{C}-\mathrm{C})$ & $\mathrm{a}_{7}\left(\mathrm{C}-\mathrm{O}_{\text {ester }}\right)$ & $\mathrm{a}_{8}\left(\mathrm{O}_{\text {ester }} \mathrm{C}\right)$ \\
\hline 1-(3-hydroxypropynyl- & 1.474 & 1.214 & 1.466 & - & - \\
1)cyclohexanol (5) & $(0.030)$ & $(0.017)$ & $(0.026)$ & - & - \\
1-(4-hydroxybutynyl- & 1.477 & 1.214 & 1.468 & - & - \\
1)cyclohexanol (6) & $(0.032)$ & $(0.018)$ & $(0.030)$ & & \\
$\begin{array}{c}\text { 1-(2-ethoxyethyl) -4-(3- } \\
\text { hydroxypropynyl-1)piperidine-4-ol }\end{array}$ & 1.474 & 1.214 & 1.460 & 1.448 & 1.455 \\
(7) & $(0.029)$ & $(0.013)$ & $(0.029)$ & $(0.029)$ & $(0.030)$ \\
$\begin{array}{c}\text { 1-(2-ethoxyethyl) -4-(4- } \\
\text { hydroxybutynyl-1)piperidine-4-ol }\end{array}$ & 1.477 & 1.214 & 1.469 & 1.446 & 1.459 \\
(8) & $(0.036)$ & $(0.016)$ & $(0.033)$ & $(0.031)$ & $(0.035)$ \\
\hline
\end{tabular}

To understand the structure of the novel molecules it is also essential to determine the angles between the triple bond and the OH-radical with respect to the hexane ring. From the data in the 
first column in Table 2 we conclude that the OH-radical cannot interact with the triple bond of the alkyne radicals because of the wide angle between these two substitutes. Also one can see that the hexane ring does not deform after adding ether substitutes, neither for the hexanol, nor the piperidine rings.

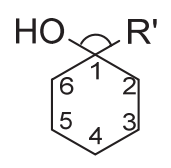

$$
\begin{aligned}
& \mathrm{R}^{\prime}=-\mathrm{C} \equiv \mathrm{C}-\mathrm{CH}_{2}-\mathrm{CH}_{2} \text { or } \\
& 4=\mathrm{N} / \mathrm{C}
\end{aligned}
$$

Figure 3. Definitions of the angles in Table 2.

Table 2. Angles (in degrees) from calculations using Nosé-Hoover thermostat. Standard deviations

\begin{tabular}{|c|c|c|c|c|c|c|c|}
\hline & $\begin{array}{c}\mathrm{O}^{-} \mathrm{C}_{\text {ring }}- \\
\mathrm{C}_{\text {triple }} \\
\end{array}$ & $\mathrm{C}_{1}$ & $\mathrm{C}_{2}$ & $\mathrm{C}_{3}$ & $\mathrm{C}_{4} / \mathrm{N}$ & $\mathrm{C}_{5}$ & $\mathrm{C}_{6}$ \\
\hline $\begin{array}{l}\text { 1-(3-hydroxypropynyl- } \\
\text { 1)cyclohexanol (5) }\end{array}$ & $109.2(3.6)$ & $\begin{array}{l}110.4 \\
(3.2)\end{array}$ & $\begin{array}{l}112.6 \\
(3.2)\end{array}$ & $\begin{array}{l}111.7 \\
(3.5)\end{array}$ & $\begin{array}{l}111.3 \\
(3.2)\end{array}$ & $\begin{array}{l}111.8 \\
(3.4)\end{array}$ & $\begin{array}{l}112.6 \\
(3.2)\end{array}$ \\
\hline $\begin{array}{l}\text { 1-(4-hydroxybutynyl- } \\
\text { 1)cyclohexanol (6) }\end{array}$ & $108.6(3.6)$ & $\begin{array}{l}109.8 \\
(3.0)\end{array}$ & $\begin{array}{l}112.8 \\
(3.3)\end{array}$ & $\begin{array}{l}111.9 \\
(3.3)\end{array}$ & $\begin{array}{l}111.7 \\
(3.2)\end{array}$ & $\begin{array}{l}111.6 \\
(3.4)\end{array}$ & $\begin{array}{l}112.8 \\
(3.3)\end{array}$ \\
\hline $\begin{array}{l}\text { 1-(2-ethoxyethyl) -4-(3- } \\
\text { hydroxypropynyl- } \\
\text { 1)piperidine-4-ol (7) }\end{array}$ & $109.2(3.5)$ & $\begin{array}{l}109.5 \\
(3.5)\end{array}$ & $\begin{array}{l}112.2 \\
(3.3)\end{array}$ & $\begin{array}{l}111.8 \\
(3.4)\end{array}$ & $\begin{array}{l}112.2 \\
(4.2)\end{array}$ & $\begin{array}{l}111.3 \\
(3.4)\end{array}$ & $\begin{array}{l}112.2 \\
(3.4)\end{array}$ \\
\hline $\begin{array}{l}\text { 1-(2-ethoxyethyl) -4-(4- } \\
\text { hydroxybutynyl- } \\
\text { 1)piperidine-4-ol (8) }\end{array}$ & $108.7(4.2)$ & $\begin{array}{l}108.6 \\
(3.5)\end{array}$ & $\begin{array}{l}112.4 \\
(3.6)\end{array}$ & $\begin{array}{l}111.2 \\
(3.6)\end{array}$ & $\begin{array}{l}111.5 \\
(3.7)\end{array}$ & $\begin{array}{l}111.2 \\
(3.3)\end{array}$ & $\begin{array}{l}112.4 \\
(3.6)\end{array}$ \\
\hline
\end{tabular}
are given within parentheses

\section{Charge distribution and charge density difference}

We also analyzed the electronic structure, and specifically the charge density, to gain more insight into the chemical reactivity of the molecules. The average overall distributions of charges among all atoms in the studied molecules are shown in Figure 4a-d. However, the most revealing data is the Hirshfield point charges on the nitrogen and the oxygen atoms. As can be seen from Figure 4c-d, the nitrogen and oxygen atoms in 1-(2-ethoxyethyl)-4-(3-hydroxypropynyl-1)piperidine-4-ol (7) and 1-(2-ethoxyethyl)-4-(4-hydroxybutynyl-1)piperidine-4-ol (8) have substantial partial negative charges. This strongly suggests that these sites are relatively reactive. Nevertheless, as it was shown in section 3.1, the nitrogen is strongly bonded to the surrounding carbon atoms and therefore cannot participate in any reactions. On the other hand, the oxygen atoms have more negative charge, which can cause interaction with neighborhood molecules. 
Our calculated point charges can be compared to those found in the General AMBER force field (GAFF) data base. ${ }^{38}$ For example, the sp-hybridized carbon atom is parameterized with the charge 0.360 , the $\mathrm{sp}^{3}$-hybridized carbon atom -0.878 , the nitrogen atom -0.530 , and the oxygen atom -0.465 . In our calculations all of molecules we see that two sp-hybridized carbon atoms (triple bonded atoms) inside one molecule have different charge values while in the standard force field they are equivalent. The difference in the charge can be explained by the influence of the cyclohexane/piperidine ring: carbon atoms located closer to the ring have more negative charge. On the other hand, the cyclohexane/piperidine ring also feels the influence of acetylene, hydroxy- and ether substitutes: charge values of $\mathrm{sp}^{3}$-hybridized carbon atoms inside ring differ depending on position of the atom and distance between the atom and the substitutes. Also one can see the common trend for all studied structures that $\mathrm{sp}^{3}$-hybridized carbon atoms closer to the triple bond have more negative charge, while the same type of carbon atoms located closer to the ethers radicals contain less negative charges. However, the $\mathrm{sp}^{3}$-hybridized carbon atom (atom 1 in Figure 3 ) connected both to the $\mathrm{OH}$-group and acetylene-containing radical has strong positive charge, which is approximately twice more than the GAFF value. This discrepancy can be explained by the double influence of the high electron density of the triple bond and the vicinity to the oxygen atom in the OH-group.

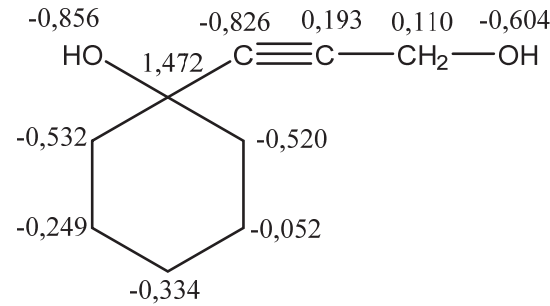

(a) 1-(3-hydroxypropynyl-1)cyclohexanol (5)

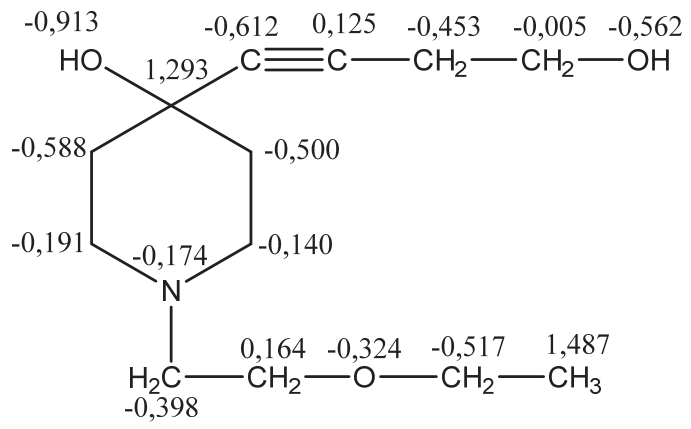

(c) 1-(2-ethoxyethyl)-4-(4-hydroxybutynyl-1) piperidine-4-ol (8)

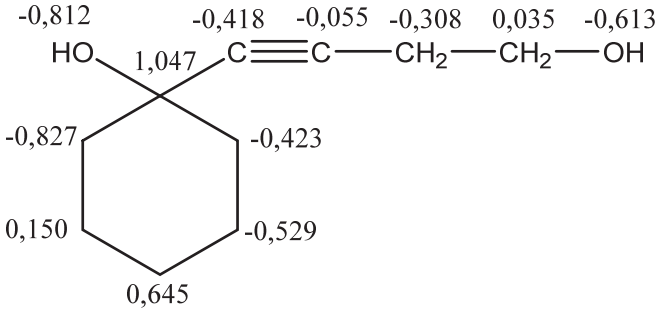

(b) 1-(4-hydroxybutynyl-1)cyclohexanol (6)

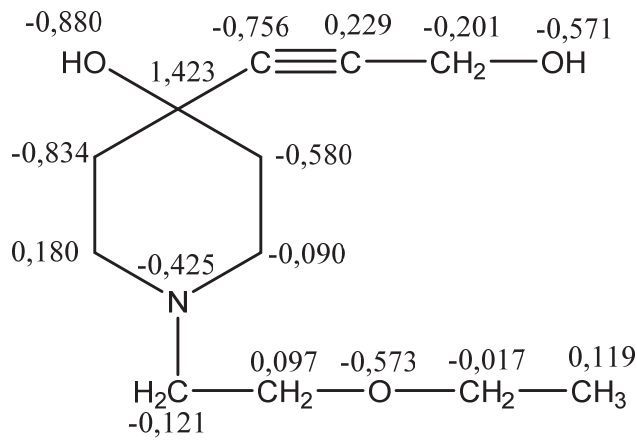

(d) 1-(2-ethoxyethyl) -4-(3-hydroxypropynyl1)piperidine-4-ol (7)

Figure 4. Charge distributions. 
We also analyzed the electronic structure of the studied molecules focusing on the charge

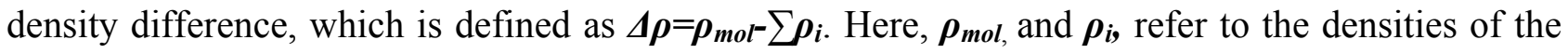
molecule and individual free atoms, respectively. Figure 5a-d show isosurfaces of the charge density difference of the studied molecules where one can clearly observe regions of electronic charge accumulation (pink) and depletion (purple). The increased accumulation of electronic charge between triple-bonded carbons is an indication of enhanced chemical bonding, which means that the triple bond is very stable. Interestingly this is in contrast to previous studies on similar molecules ${ }^{14-}$ ${ }^{20}$. Also it is clear that for all studied molecules a strong $\sigma$-type bonding appears between the carbon and the hydrogen atoms inside cyclohexane/piperidine ring (pink areas between ring carbons and hydrogens), while the overall ring has strong depletion of charge (purple areas around ring). This characterizes the cyclohexane/piperidine rings as nucleophile, which is common for aromatic and cyclic compounds. Finally, the oxygen atom in the OH-group linked to the cyclohexane/piperidine ring attracts electron density to itself and, consequently, makes the hydrogen atom of the OH-group more positive and, therefore, highly reactive.

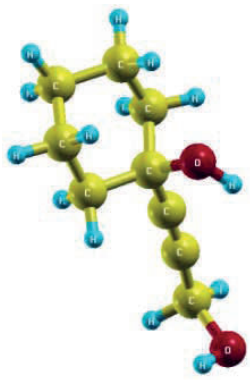

a) 1-(3-hydroxypropynyl-1)cyclohexanol (5)
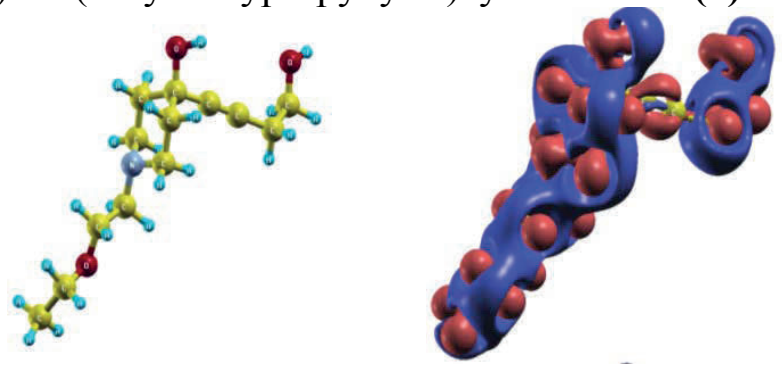

(c)1-(2-ethoxyethyl)-4-(4-hydroxybutynyl1)piperidine-4-ol (8)
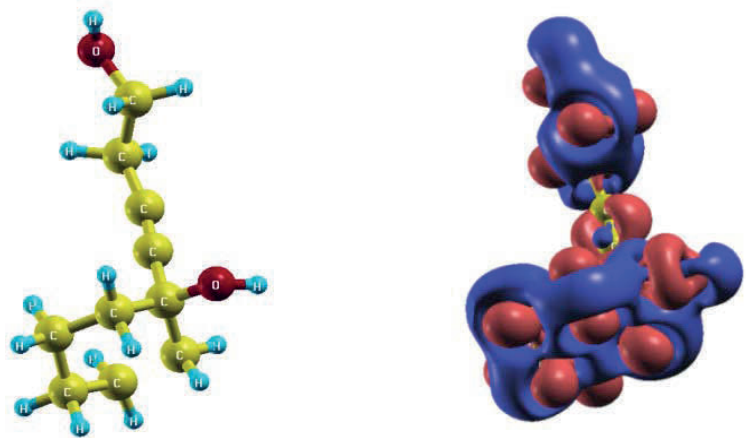

(b) 1-(4-hydroxybutynyl-1)cyclohexanol (6)
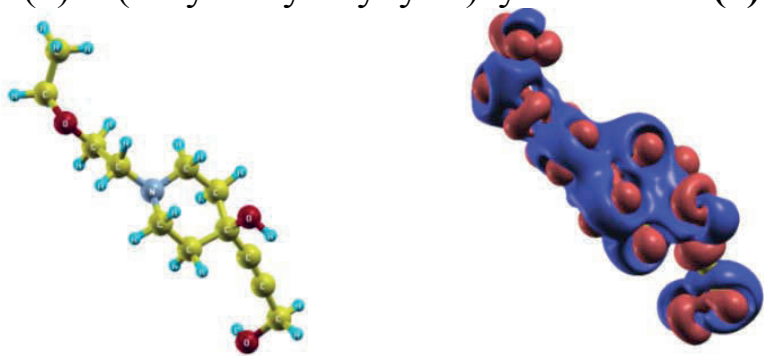

(d)1-(2-ethoxyethyl)-4-(3-hydroxypropynyl1)piperidine-4-ol (7)

Figure 5. Charge density difference (CDD). Atoms: yellow $-\mathrm{C}$, blue $-\mathrm{H}$, red $-\mathrm{O}$, light blue $-\mathrm{N}$; isosurfaces: pink - charge accumulation, purple - charge depletion.

In order to further analyze the nature of the bonds in the molecules we plotted the electron density along several planes (Figure 6). We choose to present the CDD results only for the 1-(3hydroxypropynyl-1)cyclohexanol (5). The other molecules yield very similar results. In Figure $6 \mathrm{a}$ we show the CDD for the triple bond (the cross section on the plane is shown from side and front). 
One can see that the triple-bonded carbon atoms (shown with green color) have accumulation of charge. The same can be observed for the $\mathrm{OH}$-group linked to the cyclohexane/piperidine ring (Figure 6b). We conclude that the triple bond is of $\sigma$-type and therefore has high stability.

\section{Frontier orbital analysis}

The frontier orbitals are the highest occupied (HOMO) and lowest unoccupied molecular orbitals (LUMO). Again we present the frontier orbital analysis only for 1-(3-hydroxypropynyl-1)cyclohexanol (5), since that analysis is representative for all studied molecules. A general result is that the HOMO and LUMO are concentrated in different parts of the molecule (Figure 7). We see that the HOMO is distributed relatively equally over the molecule, whereas the LUMO is more concentrated to the acetylene substitute.

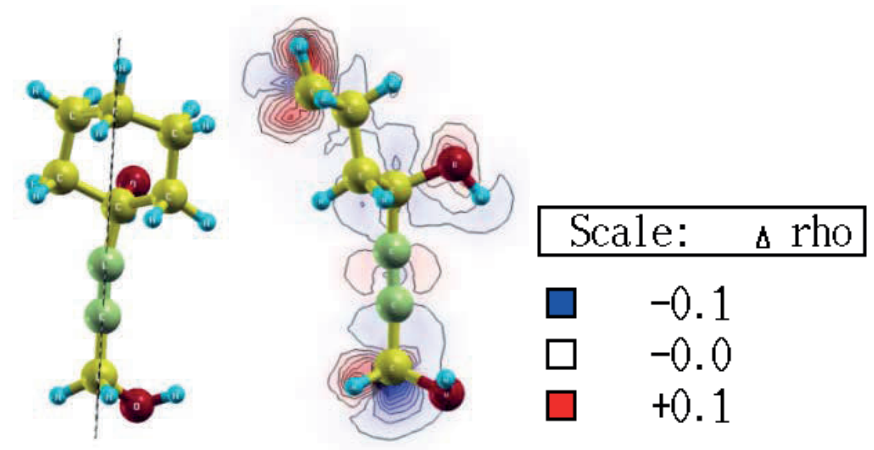

a)
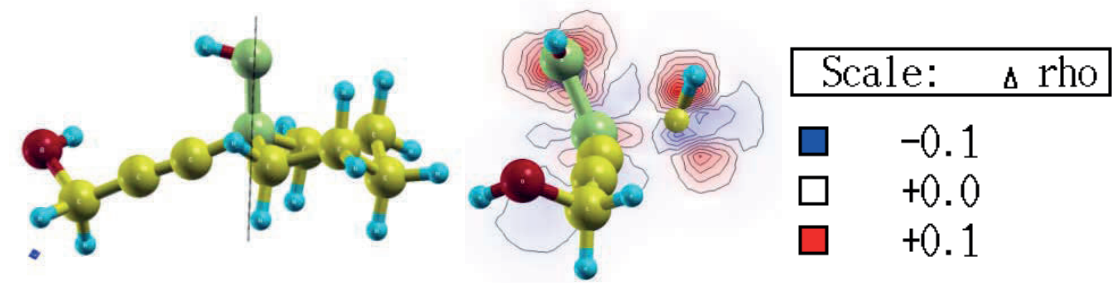

b)

Figure 6. (a) The cross section of the charge density difference plot for triple bond (front and side view) of 1-(3-hydroxypropynyl-1)cyclohexanol (5) molecule; (b) The cross section of the charge density difference plot for OH-group (front and side view) of 1-(3-hydroxypropynyl-1)cyclohexanol (5) molecule.

The strong delocalization of the LUMO on the triple-bonded radical makes the triple bond available for an electrophile attack. Furthermore, it is visible that the triple bond and the OH-group of glycol are interacting. The energy gaps for all calculated structures are shown in Table 3. One can notice that all molecules have a high HOMO-LUMO energy difference ranging between 3.4 and $4.8 \mathrm{eV}$. 


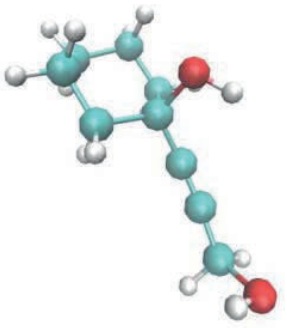

$\mathrm{a}$

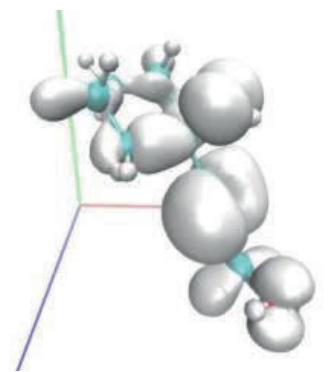

b

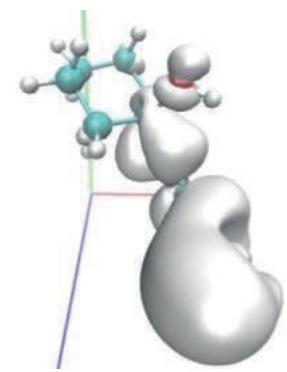

C

Figure 7. (a) 1-(3-hydroxypropynyl-1)cyclohexanol (5) structure; (b) HOMO structure; (c) LUMO structure; colors: red - oxygen, blue- carbon, white - hydrogen.

Table 3. HOMO/LUMO calculations

\begin{tabular}{cccc}
\hline & $\begin{array}{c}\mathrm{HOMO} \\
(\mathrm{eV})\end{array}$ & $\begin{array}{c}\text { LUMO } \\
(\mathrm{eV})\end{array}$ & $\begin{array}{c}\text { HOMO-LUMO } \\
\text { energy gap (eV) }\end{array}$ \\
\hline 1-(3-hydroxypropynyl-1)cyclohexanol (5) & -5.9 & -1.2 & 4.7 \\
1-(4-hydroxybutynyl-1)cyclohexanol (6) & -5.6 & -0.8 & 4.8 \\
1-(2-ethoxyethyl) -4-(3-hydroxypropynyl-1)piperidine-4-ol (7) & -4.6 & -1.2 & 3.4 \\
1-(2-ethoxyethyl) -4-(4-hydroxybutynyl-1)piperidine-4-ol (8) & -4.8 & -1.0 & 3.8 \\
\hline
\end{tabular}

\section{Conclusions}

In this work, synthesis of new piperidine-containing acetylene glycols is reported for the first time, together with a DFT-based analysis of these compounds. Different variations of the Favorskii reaction were assessed, with the aim of improving the production rate. The results of the ethynylation of cyclohexanone and piperidone-4 without solvent at low temperature were satisfactory: the reaction proceeds with an average yield more of than $50 \%$. The structures of the molecules correspond well to those expected. In accordance with IR-spectrometry and ${ }^{13} \mathrm{C} N M R$ spectra, the presence of hydroxyl groups, ester and triple bonds was confirmed in the obtained molecules. Our theoretical analysis also shows that the novel molecules contain both a triple bond and a stable cyclohexane/piperidine ring. The atomic point charges were calculated using CPMD and were seen to significantly differ from the GAFF parameters. Thus, our calculated point charges may prove very useful for the parametrization of these novel molecules in case one wish to study those further using parametrized force fields. The strong influence of the OH-group, the triple-bond containing radical and the ether-containing radical on the cyclohexane/piperidine ring was demonstrated. Also the high stability of the triple bond and high reactivity of the OH-group were demonstrated through charge density difference analysis. However, our analysis of the frontier orbitals suggests possible chemical reactions such as electrophilic attack of the triple bonds, which could be interesting to investigate in further experiments. In addition, we performed several experiments using ionic liquid, which gave low production. However, our theoretical calculations indicate that the low production rate is not due to structural molecular instability. 


\section{Experimental Section}

General. Traditionally, the ethynylation reaction is carried out in an organic solvent medium or liquid ammonia. ${ }^{30-34}$ For our case 1,4-dioxane was chosen as the most suitable and available solvent. ${ }^{35,}{ }^{36}$ However, the series of experiments in the medium of 1,4-dioxane was unsuccessful. The products were characterized by extremely low yields $(\sim 11 \%)$, as well as the presence of inseparable impurities, which hinders identification. The use of 1,4-dioxane is complicated by its capability of forming explosive peroxides, and the resinification of synthesis. In addition, the crystallization temperature of 1,4 -dioxane is $12^{\circ} \mathrm{C}$, accordingly, does not allow one to carry out the reaction at lower temperatures $\left(0-3{ }^{\circ} \mathrm{C}\right)$.

The absence of solvent in the reaction of cyclic ketones ethynylation allows providing the reaction at low temperatures $\left(0-5^{\circ} \mathrm{C}\right)$, i.e. the crystallization temperature of the involved substances is below the reaction temperature. The necessity of lower temperatures is caused by the reactivity of the acetylenic alcohols and potassium hydroxide. Mixing of potassium hydroxide and propargyl alcohol occurs with the release of heat and the formation of by-products at room temperature. Temperature decrease leads to increased product yields, reduction of substances resinification, and formation of fewer by-products during the reaction. ${ }^{34,37}$

General procedure. The cooled $\left(0-3{ }^{\circ} \mathrm{C}\right) 0.1 \mathrm{~mol}$ of $\mathrm{KOH}$ and $0.06 \mathrm{~mol}$ of acetylene alcohol were placed into three-necked flask, equipped with condenser, stirrer, thermometer, and dropping funnel. The mixture was stirred constantly for $1 \mathrm{~h}$ at the constant temperature. Afterwards, $0.02 \mathrm{~mol}$ of cooled $\left(4-6{ }^{\circ} \mathrm{C}\right)$ cyclic ketone was added with stirring, and maintained at temperature $0-5{ }^{\circ} \mathrm{C}$ for $2 \mathrm{~h}$ and at temperature $20-22{ }^{\circ} \mathrm{C}$ for $18 \mathrm{~h}$. The progress of the reaction was monitored by thin layer chromatography (TLC) (eluent: chloroform/1,4-dioxane - 30:1). After finishing of the reaction, water was added to the destruction of the reaction complex. The following steps were: extraction with chloroform for separation of organic components, solvent evaporation, and re-extraction with hexane to separate the impurities.

Schemes of reactions are shown on Figure 8.

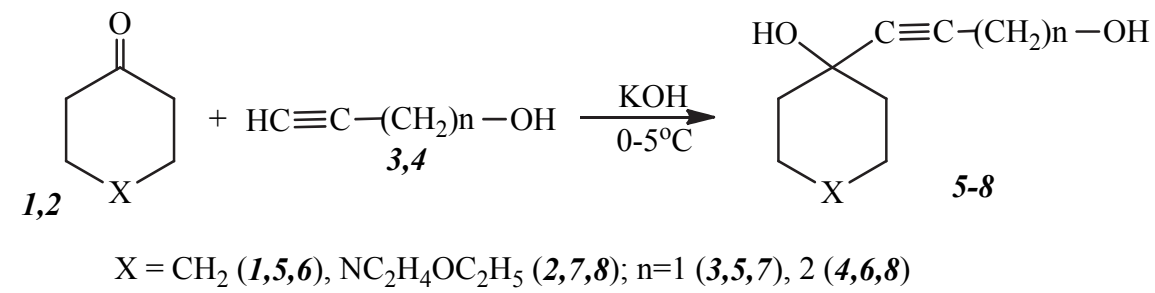

Figure 8. Scheme of the synthesis.

\section{Results and analysis}

The reaction of ethynylation with cyclic ketones and acetylene alcohols in solvent-free media was characterized by satisfactory average yields, as well as the structure of product molecules were confirmed by physical and chemical methods of analysis. Thus, during the reaction in a medium 
without solvent, it becomes possible to examine the reaction products due to their purity and stability.

${ }^{1} \mathrm{H}$ NMR spectra were recorded on a Jeol JNM-ECA 400 NMR spectrometer $(400 \mathrm{MHz})$ with HMDS as the internal standard. ${ }^{13} \mathrm{C}$ NMR spectra $(100 \mathrm{MHz})$ were also recorded with this spectrometer. IR spectra were recorded on "Nicolet 5700 FT-IR" in thin film or in KBr tablets. Elemental analyses were performed on a CE-440 (EAI Exeter Analytical Inc.). A control of the reaction and a compound individuality was performed by $\mathrm{Al}_{2} \mathrm{O}_{3}$ thin layer chromatography (TLC) method with iodine vapors development.

The study showed that declared structures were confirmed. Corresponding peaks of ester and triple bonds, as well as hydroxyl groups were shown in IR-spectrometry data. ${ }^{13} \mathrm{C}$ NMR spectra data also fully verify the structure of the synthesized acetylenic glycols. The most downfield signals in the range 81.16 - $89.31 \mathrm{ppm}$ belong to carbon triple bond. Moreover, a carbon atom of the triple bond associated with the cycle resonates in a weaker field, because of the proximity of the hydroxyl group at $\mathrm{C}_{1(4)}$. In propargyl derivatives there is strong shielding effect $(\sim 10 \mathrm{ppm})$ due to the methylene carbon adjacent to the $\mathrm{OH}$ group having a triple bond.

1-(3-Hydroxypropynyl-1)cyclohexanol (5). Pale yellow oil, yield, $1.91 \mathrm{~g}(62.0 \%), \mathrm{n}^{20}{ }_{\mathrm{D}} 1.508$. $\mathrm{R}_{\mathrm{f}} 0.11$ (eluent: chloroform/ 1,4-dioxane - 30:1). IR (thin film, $\mathrm{cm}^{-1}$ ): 1448.0; 1068.8; 3201,0; 3276,3 (O-H), $2261.6(\mathrm{C} \equiv \mathrm{C}) .{ }^{1} \mathbf{H}$ NMR (400 MHz, CDCl $): \delta 1.21\left(2 \mathrm{H}, \mathrm{m}, \mathrm{C}_{4}-\mathrm{H}_{\mathrm{ae}}\right) ; 1.49(2 \mathrm{H}$, td, $\left.\mathrm{C}_{5,3}-\mathrm{H}_{\mathrm{a}}\right) ; 1.53\left(2 \mathrm{H}, \mathrm{td}, \mathrm{C}_{5,3}-\mathrm{H}_{\mathrm{e}}\right) ; 1.63\left(2 \mathrm{H}, \mathrm{m}, \mathrm{C}_{2,6}-\mathrm{H}_{\mathrm{a}}\right) ; 1.86\left(2 \mathrm{H}, \mathrm{m}, \mathrm{C}_{2,6}-\mathrm{H}_{\mathrm{e}}\right) ; 4.26\left(2 \mathrm{H}, \mathrm{s}, \mathrm{CH}_{2} \mathrm{C} \equiv\right)$. ${ }^{13} \mathrm{C}$ NMR (100 MHz, $\left.\mathrm{CDCl}_{3}\right): \delta 23.17$ (C-3 and C-5), 25.13 (C-4), 39.67 (C-2 and C-6), 50.64 $\left(\mathrm{CH}_{2}-\mathrm{OH}\right), 69.60(\mathrm{C}-1), 82.35\left(\equiv \underline{\mathbf{C}}-\mathrm{CH}_{2}\right), 89.31\left(\mathrm{C}_{1}-\underline{\mathbf{C}} \equiv\right)$. Anal. Calcd for $\mathrm{C}_{9} \mathrm{H}_{14} \mathrm{O}_{2}: \mathrm{C}, 70.10 ; \mathrm{H}$, 9.15. Found: C, 70.18; H, 9.12.

1-(4-Hydroxybutynyl-1)cyclohexanol (6). Transparent needle crystals, yield, 1,95 g (56,9\%), mp 104,5-105 ${ }^{\circ} \mathrm{C}$ (from hexane). $\mathrm{R}_{\mathrm{f}} 0,04$ (eluent: chloroform/ 1,4-dioxane - 30:1). IR $\left(\mathrm{KBr}, \mathrm{cm}^{-1}\right)$ : 1450,7; 1038,6; 3297,8 broad (O-H), $2231,9(\mathrm{C} \equiv \mathrm{C}) .{ }^{1} \mathrm{H}$ NMR (400 MHz, $\left.\mathrm{CDCl}_{3}\right): \delta 1.26(2 \mathrm{H}, \mathrm{m}$, $\left.\mathrm{C}_{4}-\mathrm{H}_{\mathrm{ae}}\right) ; 1.54\left(4 \mathrm{H}, \mathrm{wm}, \mathrm{C}_{3,5}-\mathrm{H}_{\mathrm{a}, \mathrm{e}}\right) ; 1.69\left(2 \mathrm{H}, \mathrm{m}, \mathrm{C}_{2,6}-\mathrm{H}_{\mathrm{a}}\right) ; 1.88\left(2 \mathrm{H}, \mathrm{m}, \mathrm{C}_{2,6}-\mathrm{H}_{\mathrm{e}}\right) ; 2.50(2 \mathrm{H}, \mathrm{t}, J 6.5$ $\left.\mathrm{Hz}, \underline{\mathrm{H}}_{2} \mathrm{C} \equiv\right) ; 3.73\left(2 \mathrm{H}, \mathrm{t}, J 6.5 \mathrm{~Hz}, \underline{\mathrm{H}}_{2} \mathrm{CH}_{2} \mathrm{C} \equiv\right) .{ }^{13} \mathrm{C} \mathrm{NMR}\left(100 \mathrm{MHz}, \mathrm{CDCl}_{3}\right): \delta 23.04\left(\left(\equiv \mathrm{C}-\underline{\mathrm{CH}}_{2}\right)\right.$, 23.36 (C-3 and C-5), 25.20 (C-4), 40.08 (C-2 and C-6), $61.01\left(\mathrm{CH}_{2}-\mathrm{OH}\right), 68.70$ (C-1), 81.16 (三 $\underline{\mathbf{C}}-$ $\left.\mathrm{CH}_{2}\right), 85.96\left(\mathrm{C}_{1}-\underline{\mathbf{C}} \equiv\right)$. Anal. Calcd for $\mathrm{C}_{10} \mathrm{H}_{16} \mathrm{O}_{2}$ : C, 71.39; H, 9.59. Found: $\mathrm{C}, 71.33 ; \mathrm{H}, 9.57$.

1-(2-Ethoxyethyl) -4-(3-hydroxypropynyl-1)piperidin-4-ol (7). Transparent pale-brown oil, yield, $1,23 \mathrm{~g}(46,4 \%), \mathrm{n}_{\mathrm{D}}^{20} 1,554 . \mathrm{R}_{\mathrm{f}} 0,06$ (eluent: chloroform/ 1,4-dioxane $\left.-30: 1\right)$. IR (thin film, $\mathrm{cm}^{-1}$ ): 1447,7; 1073,5; 3370,1 broad (O-H), 1111,0 (C-O-C), 2250,1 (C $\equiv \mathrm{C}) .{ }^{1} \mathrm{H}$ NMR (400 MHz, $\left.\mathrm{CDCl}_{3}\right)$ : $\delta 1.20\left(3 \mathrm{H}, \mathrm{t}, J 6,5 \mathrm{~Hz}, \mathrm{CH}_{2} \mathrm{CH}_{2} \mathrm{OCH}_{2} \mathrm{CH}_{3}\right) ; 1.94-1.95\left(4 \mathrm{H}, \mathrm{m}, \mathrm{C}_{3,5}-\mathrm{H}_{\mathrm{ae}}\right) ; 2.45\left(2 \mathrm{H}, \mathrm{m}, \mathrm{C}_{2,6}-\mathrm{H}_{\mathrm{a}}\right) ; 2.79$ $\left(2 \mathrm{H}, \mathrm{m}, \mathrm{C}_{2,6}-\mathrm{H}_{\mathrm{e}}\right) ; 2.62\left(2 \mathrm{H}, \mathrm{t}, J 6.5 \mathrm{~Hz}, \mathrm{C}_{2} \mathrm{CH}_{2} \mathrm{OCH}_{2} \mathrm{CH}_{3}\right) ; 3.50(2 \mathrm{H}, \mathrm{q}, J 6.5 \mathrm{~Hz}$, $\left.\mathrm{CH}_{2} \mathrm{CH}_{2} \mathrm{OCH}_{2} \mathrm{CH}_{3}\right) ; 3.58\left(2 \mathrm{H}, \mathrm{t}, J 6.5 \mathrm{~Hz}, \mathrm{CH}_{2} \underline{\mathrm{C}}_{2} \mathrm{OCH}_{2} \mathrm{CH}_{3}\right) ; 4.28\left(2 \mathrm{H}, \mathrm{s}, \underline{\mathrm{C}}_{2} \mathrm{C} \equiv\right) .{ }^{13} \mathrm{C} \mathrm{NMR}$ $\left(100 \mathrm{MHz}, \mathrm{CDCl}_{3}\right): \delta 15.11\left(\mathrm{CH}_{2} \mathrm{CH}_{2} \mathrm{OCH}_{2} \underline{C H}_{3}\right), 38.65$ (C-3 and $\left.\mathrm{C}-5\right), 50.47$ (C-2 and C-6), 50.73

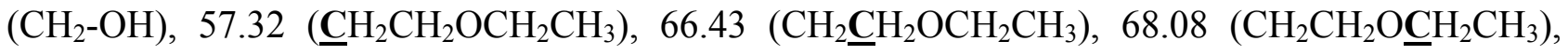
73.49 (C-4), $83.74\left(\left(\equiv \underline{\mathbf{C}}-\mathrm{CH}_{2}\right), 89.01\left(\mathrm{C}_{4}-\underline{\mathbf{C}} \equiv\right)\right.$. Anal. Calcd for $\mathrm{C}_{12} \mathrm{H}_{21} \mathrm{NO}_{3}: \mathrm{C}, 63.41 ; \mathrm{H}, 9.31 ; \mathrm{N}$, 6.16. Found: C, 63.49; H, 9.30; N, 6.12.

1-(2-Ethoxyethyl) -4-(4-hydroxybutynyl-1)piperidin-4-ol (8). Transparent pale-brown oil, yield, $1,25 \mathrm{~g}(44,3 \%), \mathrm{n}_{\mathrm{D}}^{20} 1,593$. $\mathrm{R}_{\mathrm{f}} 0,05$ (eluent: chloroform/ 1,4-dioxane $-30: 1$ ). IR (thin film, $\mathrm{cm}^{-1}$ ): 
1445,$5 ; 1053,7 ; 3315,1 ; 3367,0(\mathrm{O}-\mathrm{H}), 1116,7 \mathrm{~cm}^{-1}$ (C-O-C), 2240,7 $\mathrm{cm}^{-1}(\mathrm{C} \equiv \mathrm{C}) .{ }^{1} \mathrm{H}$ NMR $(400$ $\left.\mathrm{MHz}, \mathrm{CDCl}_{3}\right): \delta 1.19\left(3 \mathrm{H}, \mathrm{t}, J 6,5 \mathrm{~Hz}, \mathrm{CH}_{2} \mathrm{CH}_{2} \mathrm{OCH}_{2} \mathrm{C}_{3}\right) ; 1.82\left(2 \mathrm{H}, \mathrm{td}, \mathrm{C}_{3,5}-\mathrm{H}_{\mathrm{a}}\right) ; 1.88(2 \mathrm{H}, \mathrm{m}$, $\left.\mathrm{C}_{3,5}-\mathrm{H}_{\mathrm{e}}\right) ; 2.43\left(2 \mathrm{H}, \mathrm{m}, \mathrm{C}_{2,6}-\mathrm{H}_{\mathrm{a}}\right) ; 2.73\left(2 \mathrm{H}, \mathrm{m}, \mathrm{C}_{2,6}-\mathrm{H}_{\mathrm{e}}\right) ; 2.45\left(2 \mathrm{H}, \mathrm{t}, J 6.5 \mathrm{~Hz}, \mathrm{C}_{2} \mathrm{C} \equiv\right) ; 2.60(2 \mathrm{H}, \mathrm{t}, J$ $\left.6.5 \mathrm{~Hz}, \mathrm{C}_{2} \mathrm{CH}_{2} \mathrm{OCH}_{2} \mathrm{CH}_{3}\right) ; 3.39\left(2 \mathrm{H}, \mathrm{q}, J 6.5 \mathrm{~Hz}, \mathrm{CH}_{2} \mathrm{CH}_{2} \mathrm{OC}_{2} \mathrm{CH}_{3}\right) ; 3.55(2 \mathrm{H}, \mathrm{t}, J 6.5 \mathrm{~Hz}$, $\left.\mathrm{CH}_{2} \underline{\mathrm{C}}_{2} \mathrm{OCH}_{2} \mathrm{CH}_{3}\right) ; 3.69\left(2 \mathrm{H}, \mathrm{t}, J 6.5 \mathrm{~Hz}, \underline{\mathrm{C}}_{2} \mathrm{CH}_{2} \mathrm{C} \equiv\right) .{ }^{13} \mathrm{C} \mathrm{NMR}\left(100 \mathrm{MHz}, \mathrm{CDCl}_{3}\right): \delta 15.12$ $\left(\mathrm{CH}_{2} \mathrm{CH}_{2} \mathrm{OCH}_{2} \underline{\mathbf{C H}}_{3}\right), 23.02\left(\underline{\mathbf{C H}}_{2} \mathrm{C} \equiv\right), 39.09(\mathrm{C}-3$ and $\mathrm{C}-5), 50.78(\mathrm{C}-2$ and $\mathrm{C}-6), 57.45$ $\left(\underline{\mathbf{C}} \mathrm{H}_{2} \mathrm{CH}_{2} \mathrm{OCH}_{2} \mathrm{CH}_{3}\right), 60.84\left(\mathrm{CH}_{2}-\mathrm{OH}\right), 66.42\left(\mathrm{CH}_{2} \underline{\mathbf{C}} \mathrm{H}_{2} \mathrm{OCH}_{2} \mathrm{CH}_{3}\right), 69.18\left(\mathrm{CH}_{2} \mathrm{CH}_{2} \mathrm{O}_{\mathbf{C H}} \mathrm{CH}_{3}\right)$, 70.10 (C-4), $82.05\left(\left(\equiv \underline{\mathbf{C}}-\mathrm{CH}_{2}\right), 85.08\left(\mathrm{C}_{4}-\underline{\mathbf{C}} \equiv\right)\right.$. Anal. Calcd for $\mathrm{C}_{13} \mathrm{H}_{23} \mathrm{NO}_{3}: \mathrm{C}, 64.70 ; \mathrm{H}, 9.61 ; \mathrm{N}$, 5.80. Found: $\mathrm{C}, 64.86 ; \mathrm{H}, 9.5 ; \mathrm{N}, 5.98$.

\section{Acknowledgements}

The authors acknowledge financial support from Vetenskapsrådet (VR), The Royal Swedish Academy of Sciences (KVA), the Knut and Alice Wallenberg Foundation (KAW), Carl Tryggers Stiftelse (CTS), Swedish Energy Agency (STEM), Swedish Foundation for Strategic Research (SSF), and Erasmus Mundus Action 2 TARGET II consortium. The authors are grateful to Dr. T. Seylkhanov from Kokshetau State University for collaboration. The computations were performed on resources provided by the Swedish National Infrastructure for Computing (SNIC) at the National Supercomputer Center (NSC), Linköping University, the PDC Centre for High Performance Computing (PDC-HPC), KTH Royal Institute of Technology, and the High Performance Computing Center North (HPC2N), Umeå University.

\section{Supplementary Material}

Supplementary material includes atom coordinates and absolute energies of calculated structures. This material is available free of charge.

\section{References}

1. $\quad$ Azerbaev, I.; Erzhanov, K.; Bosyakov, Yu. Chem. Heterocyc. Compd. 1971, 7(5), 584-586. http://dx.doi.org/10.1007/BF00945498

2. Azerbaev, I.; Sarbaev, T.; Erzhanov, K. Chem. Heterocyc Compd. 1970, 4(1), 94-95. http://dx.doi.org/10.1007/BF00478092

3. Azerbaev, I. N.; Sarbaev, T. G.; Basymbekov, M. B. Khim. Geterotsikl. Soedin. 1968, 4(5), 833-835.

4. Azerbaev, I.; Bosyakov, Yu.; Erzhanov, K. Chem. Heterocyc. Compd. 1970, 6(12), 15361541.

http://dx.doi.org/10.1007/BF00522576

5. Abdulganeeva, S.; Grishina, G.; Potapov, V.; Erzhanov, K.; Shapovalov, A. Chem. Heterocyc. Compd. 1983, 19(4), 408-411. 


\section{http://dx.doi.org/10.1007/BF00516210}

6. State of Food Insecurity in the World (SOFI 2013). The Food and Agriculture Organization (FAO), the International Fund for Agricultural Development (IFAD) and the World Food Programme (WFP); 2013.

7. The World Health Organization. The World Health Report 2000-Health Systems: Improving Performance. Geneva; 2000.

8. Hunger pains: there is enough food in the world for everyone, but one out of every seven people on Earth is hungry. Canada and the World Backgrounder 2003, 69(1), 18.

9. Diouf, J. OECD Observer. 2003, p 21(2).

10. Burke, J.; Kuylenstierna, J. Perspective papers on Water and Climate Change Adaptation; 2009.

11. Favorskii, A. E. Zhurnal Russkago Fiziko-Khimicheskago Obshchestva, 1905, 37, 643-645.

12. Smith, M.; March, J. March's advanced organic chemistry. Wiley-Interscience, 2001.

13. Kohn, W.; Becke, A. D.; Parr, R. G. J. Phys. Chem. 1996, 100, 12974-12980. http://dx.doi.org/10.1021/jp9606691

14. Chen, D. M.; Li, Y-L.; Phillips, D. L. J. Org. Chem. 2002, 67, 4619-4622. http://dx.doi.org/10.1021/jo0256078

15. Baei, M. T.; Peyghan, A. A.; Bagheri, Z. Struct. Chem. 2013, 24(4), 1007-1013. http://dx.doi.org/10.1007/s11224-012-0129-5

16. Tekin, A.; Jansen, G. Phys. Chem. Chem. Phys. 2007, 9(14), 1680-1687. http://dx.doi.org/10.1039/B618997K

17. Yue, L.; Baer, T. J. Phys. Chem. A 2002, 106(37), 8658-8666. http://dx.doi.org/10.1021/jp021205s

18. Fan, X.-W.; Ju, X.-H.; Xiao, H.-M. J. Hazard. Mater. 2008, 156(1), 342-34. http://dx.doi.org/10.1016/j.jhazmat.2007.12.024

19. Güllüoğlu, M. T.; Erdoğdu, Yu.; Yurdakul, Ş. J. Mol. Struct. 2007, 834, 540-547. http://dx.doi.org/10.1016/j.molstruc.2007.01.023

20. Sundaraganesan, N.; Elango, G.; Meganathan, C.; Karthikeyan, B.; Kurt, M. Mol Simul. 2009, 35(9), 705-713.

http://dx.doi.org/10.1080/08927020902873992

21. Hanwell, M. D.; et al. J. Cheminf. 4 (2012): 17. PMC. Web. 27 Mar. 2015.

22. Car, R.; Parrinello, M. Phys. Rev. Lett. 1985, 55, 2471-2474.

http://dx.doi.org/10.1103/PhysRevLett.55.2471

23. Giannozzi, P.; et al. J. Phys.: Condens. Matter. 2009, 21, 395502.

http://dx.doi.org/10.1088/0953-8984/21/39/395502

24. Kokalj, A. Comp. Mater. Sci. 2003, 28, 155.

http://dx.doi.org/10.1016/S0927-0256(03)00104-6

25. Becke, A. D. Phys. Rev. A. 1988, 38, 3098.

http://dx.doi.org/10.1103/PhysRevA.38.3098

26. Lee, C.; Yang, W.; Parr, R. G. Phys. Rev. B. 1988, 37, 785.

http://dx.doi.org/10.1103/PhysRevB.37.785 
27. Hoover, W. G. Phys. Rev. A. 1985, 31, 1695-1697.

http://dx.doi.org/10.1103/PhysRevA.31.1695

28. Hirshfeld, F. L. Theoret. Chim. Acta 1977, 44, 129. http://dx.doi.org/10.1007/BF00549096

29. Boero, M.; Parrinello, M.; Terakura, T.; Ikeshoji, T.; Liew, C. C. Phys. Rev. Lett. 2003, 90, 226403.

http://dx.doi.org/10.1103/PhysRevLett.90.226403

30. Bazhykova, K. B.; Poplavskaya, I. A.; Praliev, K. D. Chem. Heterocyc. Compd. 2005, 41(11), 1386-1389.

http://dx.doi.org/10.1007/s10593-006-0006-5

31. Trofimov B. A. ChemInform 1996, 27(33).

32. Trofimov, B.; Vasil'tsov, A.; Mikhaleva, A.; Petrova, O.; Polubentsev, A. Bulletin of the Academy of Sciences of the USSR, Division of chemical science 1989, 38(12), 2643-2644.

http://dx.doi.org/10.1007/BF00962478

33. Vasil'tsov, A.; Trofimov, B.; Amosova, S. Bulletin of the Academy of Sciences of the USSR, Division of Chemical Sciences 1987, 36(8), 1653 -1658.

http://dx.doi.org/10.1007/BF00960125

34. Trofimov, B. A. Rus. Chem. Rev. 2007, 76(6), 507-527. http://dx.doi.org/10.1070/RC2007v076n06ABEH003712

35. Trofimov, B. A.; Schmidt, E. Yu.; Zorina, N. V.; Skital'tseva, E. V.; Mikhaleva, A. I. Chem. Heterocyc. Compd. 2010, 46(5), 623-624.

http://dx.doi.org/10.1007/s10593-010-0557-3

36. Schmidt, E. Yu.; Zorina, N. V.; Skitaltseva, E. V.; Ushakov, I. A.; Mikhaleva, A. I.; Trofimov, B. A. Tetrahedron Lett. 2011, 52(29), 3772-3775.

http://dx.doi.org/10.1016/j.tetlet.2011.05.056

37. Trofimov, A.; Nosyreva, V. V.; Mal'kina, A. G. Rus. J. Org. Chem. 2005, 41(9), 1254-1259. http://dx.doi.org/10.1007/s11178-005-0331-7

38. Case, D. A.; Darden, T. A.; and etc., AMBER 9, University of California, San Francisco 2006. 